\title{
Antibiotic Resistant and Biofilm-Associated Escherichia coli Isolates from Diarrheic and Healthy Dogs
}

\author{
Lívia Karahutová $^{1}$, René Mandelík ${ }^{2}$ and Dobroslava Bujňáková ${ }^{1, *(1)}$ \\ 1 Institute of Animal Physiology, Centre of Biosciences of the Slovak Academy of Sciences, Šoltésovej 4-6, \\ 04001 Košice, Slovakia; karahutova@saske.sk \\ 2 Department of Epizootiology, Parasitology and Protection of One Health, University of Veterinary Medicine \\ and Pharmacy in Košice, Komenského 73, 04001 Košice, Slovakia; rene.mandelik@uvlf.sk \\ * Correspondence: dbujnak@saske.sk; Tel.: +421-55-727-62-76
}

check for updates

Citation: Karahutová, L.; Mandelík, R.; Bujňáková, D. Antibiotic Resistant and Biofilm-Associated Escherichia coli Isolates from Diarrheic and Healthy Dogs. Microorganisms 2021, 9, 1334. https://doi.org/10.3390/ microorganisms 9061334

Academic Editor: Charles M. Dozois

Received: 31 May 2021

Accepted: 16 June 2021

Published: 19 June 2021

Publisher's Note: MDPI stays neutral with regard to jurisdictional claims in published maps and institutional affiliations.

Copyright: (c) 2021 by the authors. Licensee MDPI, Basel, Switzerland. This article is an open access article distributed under the terms and conditions of the Creative Commons Attribution (CC BY) license (https:/ / creativecommons.org/licenses/by/ $4.0 /)$.

\begin{abstract}
Bacteria isolated from companion animals are attracting concerns in a view of public health including antimicrobial resistance and biofilm development, both contributing to difficult-to-treat infections. The purpose of this study was to evaluate the minimum inhibitory concentrations (MIC) of 18 antibiotics in Escherichia coli isolated from two groups of dogs (healthy and diarrheic). Isolates were classified into phylogroups, examined for the presence of resistance genes and biofilm-formation capacity. In healthy dogs, phylogenetic analysis showed that $47.37 \%$ and $34.22 \%$ of E. coli isolates belonged to commensal groups (A; B1) in contrast to diarrheic dogs; $42.2 \%$ of isolates were identified as the B2 phylogroup, and these E. coli bacteria formed a stronger biofilm. The results of healthy dogs showed higher MIC levels for tetracycline $(32 \mathrm{mg} / \mathrm{L})$, ampicillin $(64 \mathrm{mg} / \mathrm{L})$, ciprofloxacin $(8 \mathrm{mg} / \mathrm{L})$ and trimethoprim-sulphonamide $(8 \mathrm{mg} / \mathrm{L})$ compared to clinical breakpoints. The most detected gene encoding plasmid-mediated resistance to quinolones in the healthy group was qnr $\mathrm{B}$, and in dogs with diarrhea, qnrS. The resistance genes were more frequently detected in healthy dogs. The presence of the integron int 1 and the transposon $t n 3$ increases the possibility of transfer of many different cassette-associated antibiotic-resistance genes. These results suggest that dogs could be a potential reservoir of resistance genes.
\end{abstract}

Keywords: E. coli; dogs; antimicrobial resistance; biofilm; phylogenetic groups

\section{Introduction}

Escherichia coli (E. coli) is a highly versatile bacterium that ranges from harmless gut commensal to intra- or extra- intestinal pathogens [1]. Commensal E. coli colonizes in the gastrointestinal tract within a few hours after birth. Although these strains are part of the normal microbiota of humans and animals, several clinical reports have implicated E. coli as the etiological agent of diarrhea in humans and their companion animals [2,3]. Previously, the most extensive investigations of $E$. coli infection have been described in cattle, sheep and pigs. However, recently, the dogs and cats that live in close proximity to humans have become a focus of disease transmission studies. Because the contact between humans and pets has increased, the possibility of pathogenic microorganism transmission between these organisms is very high. The fecal shedding of E. coli by companion animals represents an important source of the zoonotic transmission of pathogenic agents [2].

The prevalence of drug-resistant bacteria, caused among other things by an excessive use of antibiotics, is an increasing problem due to the possible transmission of resistant bacteria or their resistance genes between animals and humans via direct or indirect contact, such as through food/feed and the environment. Drug-resistant commensal E. coli isolates may constitute a significant reservoir of antibiotic-resistance determinants, which can spread to those bacteria that are pathogenic for animals and/or humans. Another problem is biofilm development, since the biofilm matrix gives an additional resistance power to the bacteria which makes them not only tolerant to harsh conditions but also resistant to 
antibiotics. This leads to the emergence of bad-bugs infections, such as multi-drug resistant, extensively drug resistant and totally drug resistant types of bacteria [4].

For a long time, the focus of research was mostly on antimicrobial resistance (AMR) monitoring in food-producing animals [5]. Recently, dogs and cats have been described as potential vehicles for AMR; however, the data remained scarce. Therefore, it was found necessary to take a closer look at the situation existing in companion animals. Furthermore, approaching any issue from a One Health perspective necessitates looking at the interactions between people, domestic animals including pets, wildlife, plants and our environment [6].

Dogs and cats represent potential sources for the spread of AMR, due to the extensive use of broad-spectrum antimicrobial agents in these animals (even those critically important for human medicine, such as third generation cephalosporins and fluoroquinolones, colistin, tetracyclines and macrolides) and their close and intensive contact with humans [7]. Moreover, pet feces on the ground of urban areas represent a significant public-health problem [8].

So far, especially within the European Union's member states, the monitoring of the existing situation concerning AMR in indicator bacteria such as E. coli of companion animals has been done sporadically. To the best of our knowledge, phenotypic resistance profiles of $282 \mathrm{E}$. coli isolates were determined to be present in dogs and cats in three European countries (Belgium, Italy and the Netherlands), of which 19\% were isolated after antibiotic treatment of the monitored animals. Furthermore, the situation in Sweden [9] regards antibiotic resistance in the bacteria from humans and animals (including dogs), and a 331 indicator E. coli was mapped in the years 2006 and 2012. A similar situation exists throughout the European Union (EU) including the Slovak Republic, where the data on indicator E. coli isolates are only related to poultry and the meat derived thereof. A different situation is presented in the monitoring of AMR in clinical bacteria causing various infections [10]. However, studies of companion animals demonstrating the current situation of AMR concerning the indicator E. coli in the EU including the Slovak Republic are rather rare.

Therefore, the objectives of our study were to evaluate the phenotypic and genotypic AMR of commensal indicator and diarrheic E. coli isolated from Slovakian canine fecal samples using the standardized automated diagnostic system Bel-MIDITECH to classify their phylogenetic relatedness and to determine their biofilm-forming capacity as one of the factors contributing to increased resilience.

\section{Materials and Methods}

\subsection{Canine Samples, Isolation and Identification of E. coli}

The rectal swabs from 38 healthy non-antimicrobial treated dogs and 45 dogs with diarrhea, of varying breeds and from different households, were inoculated overnight at $37^{\circ} \mathrm{C}$ in buffered peptone water (Oxoid, Basingstoke, UK). The samples from the diarrheal dogs were taken before an antibiotic treatment. The samples were then subcultured on MacConkey Agar (Oxoid, Basingstoke, UK) and UriSelect Agar (Bio-Rad Laboratories, Hercules, CA, USA) overnight at $37^{\circ} \mathrm{C}$. The colonies were isolated, identified and confirmed as E. coli using the MALDI-TOF MS (Matrix-Assisted Laser Desorption Ionization-Time of Flight, Mass Spectrometry) biotyper (Bruker Daltonics, Bremen, Germany) according to the methods described by Bessède et al. [11] and ENTEROtest24 (Erba Lachema Brno, Czech Republic) for the routine identification of important species of the Enterobacterales family within $24 \mathrm{~h}$. One colony of E. coli was isolated from each sample.

\subsection{Phylogenetic Groups}

The form of the phylogenetic analysis was determined by using a new method, according to Clermont et al. [12]. The quadruplex polymerase chain reaction (PCR) was used to determine the phylogroup of each of the 83 isolates corresponding to the presence or absence of the genes $\operatorname{arp} \mathrm{A}, \operatorname{chu} \mathrm{A}, y j a \mathrm{~A}$ and TspE4.C2. All the isolates assigned to phylogroup 
A were screened using a C-specific primer trpA (trpAgpC). Similarly, all the D phylogroup isolates were screened using an E-specific primer arpA (ArpAgpE). The oligonucleotide primers, annealing and references are listed in Table 1.

Table 1. Primers used for the PCR detection of resistance genes and phylogroups.

\begin{tabular}{|c|c|c|c|c|}
\hline Gene & Primer Sequences $\left(5^{\prime}-3^{\prime}\right)$ & Annealing $\left({ }^{\circ} \mathrm{C}\right)$ & $\begin{array}{l}\text { Size Product } \\
\text { (bp) }\end{array}$ & Reference \\
\hline int1 & $\begin{array}{l}\text { F:GGGTCAAGGATCTGGATTTCG } \\
\text { R:ACATGCGTGTAAATCATCGTCG }\end{array}$ & 62 & 483 & [13] \\
\hline $\operatorname{tn} 3$ & $\begin{array}{l}\text { F:CACGAATGAGGGCCGACAGGA } \\
\text { R:ACCCACTCGTGCACCCAACTG }\end{array}$ & 58 & 500 & [14] \\
\hline$d f r A$ & $\begin{array}{l}\text { F:GTGAAACTATCACTAATGG } \\
\text { R:TTAACCCTTTTGCCAGATTT }\end{array}$ & 55 & 474 & [15] \\
\hline$d f r B$ & $\begin{array}{l}\text { F:GATCGCCTGCGCAAGAAATC } \\
\text { R:AAGCGCAGCCACAGGATAAAT }\end{array}$ & 60 & 141 & [15] \\
\hline tet $A$ & $\begin{array}{c}\text { F:GGCCTCAATTTCCTGACG } \\
\text { R:AAGCAGGATGTAGCCTGTGC }\end{array}$ & 55 & 372 & [16] \\
\hline tet $B$ & $\begin{array}{c}\text { F:GAGACGCAATCGAATTCGG } \\
\text { R:TTTAGTGGCTATTCTTCCTGCC }\end{array}$ & 55 & 228 & [16] \\
\hline$o q x A$ & $\begin{array}{l}\text { F:GACAGCGTCGCACAGAATG } \\
\text { R:GGAGACGAGGTTGGTATGGA }\end{array}$ & 62 & 339 & [17] \\
\hline$o q x B$ & $\begin{array}{l}\text { F:CGAAGAAAGACCTCCCTACCC } \\
\text { R:CGCCGCCAATGAGATACA }\end{array}$ & 62 & 240 & [17] \\
\hline qерA & $\begin{array}{c}\text { F:GCAGGTCCAGCAGCGGGTAG } \\
\text { R:CTTCCTGCCCGAGTATCGTG }\end{array}$ & 60 & 199 & [18] \\
\hline$q n r S$ & $\begin{array}{l}\text { F:ACGACATTCGTCAACTGCAA } \\
\text { R:TAAATTGGCACCCTGTAGGC }\end{array}$ & 53 & 417 & [19] \\
\hline$q n r A$ & $\begin{array}{l}\text { F:ATTTCTCACGCCAGGATTTG } \\
\text { R:GATCGGCAAAGGTTAGGTCA }\end{array}$ & 53 & 516 & [19] \\
\hline$q n r B$ & $\begin{array}{c}\text { F:GATCGTGAAAGCCAGAAAGG } \\
\text { R:ACGATGCCTGGTAGTTGTCC }\end{array}$ & 53 & 469 & [19] \\
\hline$a a c\left(6^{\prime}\right)-I b-c r$ & $\begin{array}{l}\text { F:GATCTCATATCGTCGAGTGGTGG } \\
\text { R:GAACCATGTACACGGCTGGAC }\end{array}$ & 58 & 435 & [19] \\
\hline$m c r-1$ & $\begin{array}{l}\text { F:CGGTCAGTCCGTTTGTTC } \\
\text { R:CTTGGTCGGTCTGTAGGG }\end{array}$ & 58 & 309 & {$[20]$} \\
\hline$m c r-2$ & $\begin{array}{l}\text { F: TGTTGCTTGTGCCGATTGGA } \\
\text { R:AGATGGTATTGTTGGTTGCTG }\end{array}$ & 58 & 567 & [21] \\
\hline sul1 & $\begin{array}{l}\text { F:CGGCGTGGGCTACCTGAACG } \\
\text { R:GCCGATCGCGTGAAGTTCCG }\end{array}$ & 69 & 433 & {$[22]$} \\
\hline sul2 & $\begin{array}{l}\text { F:GCGCTCAAGGCAGATGGCATT } \\
\text { R:GCGTTTGATACCGGCACCCGT }\end{array}$ & 69 & 293 & [22] \\
\hline sul3 & $\begin{array}{l}\text { F: GAGCAAGATTTTTGGAATCG } \\
\text { R:CATCTGCAGCTAACCTAGGGCTTTGA }\end{array}$ & 51 & 990 & [23] \\
\hline $\operatorname{arp} A$ & $\begin{array}{l}\text { F:AACGCTATTCGCCAGCTTGC } \\
\text { R:TCTCCCCATACCGTACGCTA }\end{array}$ & 59 & 400 & [12] \\
\hline $\operatorname{chuA}$ & $\begin{array}{l}\text { F:ATGGTACCGGACGAACCAAC } \\
\text { R:TGCCGCCAGTACCAAAGACA }\end{array}$ & 59 & 288 & [12] \\
\hline yjaA & $\begin{array}{l}\text { F:CAAACGTGAAGTGTCAGGAG } \\
\text { R: AATGCGTTCCTCAACCTGTG }\end{array}$ & 59 & 211 & [12] \\
\hline TspE4.C2 & $\begin{array}{l}\text { F: CACTATTCGTAAGGTCATCC } \\
\text { R: AGTTTATCGCTGCGGGTCGC }\end{array}$ & 59 & 152 & [12] \\
\hline $\operatorname{arp} A g p E$ & $\begin{array}{l}\text { F:GATTCCATCTTGTCAAAATATGCC } \\
\text { R:GAAAAGAAAAAGAATTCCCAAGAG }\end{array}$ & 57 & 301 & [24] \\
\hline $\operatorname{trp} A g p C$ & $\begin{array}{l}\text { F:AGTTTTATGCCCAGTGCGAG } \\
\text { R:TCTGCGCCGGTCACGCCC }\end{array}$ & 59 & 219 & [24] \\
\hline$b l a_{\mathrm{TEM}-1}$ & $\begin{array}{l}\text { F:ATGAGTATTCAACATTTCCG } \\
\text { R:CCAATGCTTAATCAGTGAGG }\end{array}$ & 55 & 858 & [25] \\
\hline$b l a_{\mathrm{SHV}}$ & $\begin{array}{c}\text { F:ATGCGTTATATTCGCCTGTG } \\
\text { R:TTAGCGTTGCCAGTGCTCGATG }\end{array}$ & 58 & 301 & [26] \\
\hline cit & $\begin{array}{l}\text { F: TGGCCAGAACTGACAGGCAAA } \\
\text { R: TTTCTCCTGAACGTGGCTGGC }\end{array}$ & 64 & 462 & [27] \\
\hline
\end{tabular}

Abbreviations: int $1=$ integron; $\operatorname{tn} 3=$ transposon; resistance to trimethoprim $=d f r A, d f r B ;$ resistance to tetracycline $=$ tet $A$, tet $B ;$ quinolone resistance $=o q x A, o q x B$, aac $\left(6^{\prime}\right)-I b-c r$, qepA, qnrS, qnrA, qnrB; resistance to colistin $=m c r-1, m c r-2$; sulfonamide resistance $=s u l 1$, sul2 and sul3; $\beta$-lactamase encoding bla $a_{\mathrm{TEM}-1}$, bla $\mathrm{SHV}$ and ampicillinase-cit. Phylogenetic grouping: $\operatorname{arp} \mathrm{A}, \operatorname{chuA}$, yjaA, DNA fragment TspE4.C2 and requires additional testing for specific genes in the $\mathrm{E}(\operatorname{arp} A g p \mathrm{E})$ and $\mathrm{C}(\operatorname{trp} A g p \mathrm{C})$ groups. 


\subsection{Antimicrobial Sensitivity}

The minimum inhibitory concentration (MIC) testing was performed according to Gattringer et al. [28] using the Slovakian automated diagnostic system Bel-MIDITECH (Bratislava, Slovakia) consisting of ampicillin (AMP), ampicillin + sulbactam (SAM), piperacillin + tazobactam (TZP), cefuroxime (CXM), cefotaxime (CTX), ceftazidime (CAZ), cefoperazone + sulbactam (SPZ), cefepime (FEP), ertapenem (ETP), meropenem (MEM), gentamicin (GEN), tobramycin (TOB), amikacin (AMI), tigecycline (TGC), ciprofloxacin (CIP), tetracycline (TET), colistin (COL) and trimethoprim + sulfonamide (COT). The results of the MIC values of each antibiotic were interpreted according to the clinical breakpoints (CBPs) described by The European Committee on Antimicrobial Susceptibility Testing (EUCAST) 2020 [29].

\subsection{Detection of Resistance Genes}

The strains were investigated for the presence of resistance genes using primers, as shown in Table 1, by means of multiplex and/or single PCR assays. The amplifications were carried out in a single tube with a volume of $25 \mu \mathrm{L}$, utilizing TaqI polymerase (Solis Biodyne, Estonia) with $10 \times$ Buffer B without $\mathrm{Mg}^{2+}(2-2.5 \mu \mathrm{L})$; deoxynucleotide triphosphates (dNTPs) mix (Promega, Madison, WI, USA; $2.5 \mu \mathrm{L}) ; 25 \mathrm{mM} \mathrm{MgCl} 2(1.5-2.5 \mu \mathrm{L})$; $10-20 \mathrm{pmol} / \mu \mathrm{L}$ primers (Lambda Life, Bratislava, Slovakia; $0.1-0.2 \mu \mathrm{L}$ ); $10-100 \mathrm{ng} / \mu \mathrm{L}$ DNA template (1-1.5 $\mu \mathrm{L})$; and deionized sterile water. The PCR program consisted of an initial denaturation step at $95^{\circ} \mathrm{C}$ for $4 \mathrm{~min}$, followed by 32 cycles of DNA denaturation at $95^{\circ} \mathrm{C}$ for $50 \mathrm{~s}$, primer annealing at $50-69^{\circ} \mathrm{C}$ (according to primers) for $50 \mathrm{~s}$ and primer extension at $72{ }^{\circ} \mathrm{C}$ for $1 \mathrm{~min}$. After the last cycle, a final extension step at $72{ }^{\circ} \mathrm{C}$ for $7 \mathrm{~min}$ was added. The presence of genes for a resistance to trimethoprim-dihydrofolate reductase enzymes $d f r \mathrm{~A}$ and $d f r \mathrm{~B}$; sulfonamide resistance-sul1, sul2 and sul3; resistance to tetracycline-tet $\mathrm{A}$ and tet $\mathrm{B}$; quinolone resistance- $o q x \mathrm{~A}, o q x \mathrm{~B}$; additional plasmid mediated quinolone resistance determinants-aac ( $\left.6^{\prime}\right)-I b-c r$; quinolone extrusion by qep $\mathrm{A}, q n r \mathrm{~S}$, $q n r \mathrm{~A}$ and $q n r \mathrm{~B}$; resistance to colistin encoded by $m c r-1$ and $m c r-2 ; \beta$-lactamase encoding $b l a_{\mathrm{TEM}-1}, b l a_{\mathrm{SHV}}$ and ampicillinase-cit were monitored. Moreover, we evaluated the presence of genes for integron int 1 and transposon $t n 3$, because they are capable of capturing and expressing the genes contained in cassette-like structures that represent a substantial proportion of the resistance determinants in Gram-negative bacteria.

\subsection{Detection of Biofilm Formation}

The ability for biofilm formation was assessed in a quantitative assay using a microtiterplate test (Nunc, Roskilde, Denmark). Strains were grown on Brain Heart Infusion (BHI) agar, and colonies were re-suspended in a BHI broth (Oxoid, Basingstoke, UK) to reach the 0.5 suspension of McFarland's standard, and volumes of $200 \mu \mathrm{L}$ of these cell suspensions were transferred to the wells of the microplate. For the negative control, we used an uninoculated BHI medium. After incubation $\left(24 \mathrm{~h}\right.$ at $\left.37^{\circ} \mathrm{C}\right)$, the adherent cells were washed three times using a saline solution and stained with a $0.1 \%$ crystal violet solution (Mikrochem, Pezinok, Slovakia). The adhering dye was dissolved with $30 \%$ acetic acid, and the optical density was measured at $570 \mathrm{~nm}$ in the Synergy HT Multi-Mode Microplate Reader (BioTek, Winooski, VT, USA). For classification, we used the average optical density (OD) value and cut-off value (ODc) (defined as three standard deviations (SD) above the mean OD of the negative control). The final OD value of a tested strain was expressed as the average OD value of the strain reduced by the ODc value. For the interpretation of the results, the strains were divided into the categories described by Stepanovic et al. [30]: $\mathrm{OD} \leq \mathrm{ODc}=$ non-biofilm producer; $\mathrm{ODc}<\mathrm{OD} \leq 2 \times \mathrm{ODc}=$ weak biofilm $; 2 \times \mathrm{ODc}<\mathrm{OD}$ $\leq \times \mathrm{ODc}=$ moderate and $4 \times \mathrm{ODc}<\mathrm{OD}=$ strong biofilm producer. 


\section{Results and Discussion}

\subsection{Antimicrobial Sensitivity}

A total of $38 \mathrm{E}$. coli isolates recovered from the fecal samples of healthy non-antimicrobial treated dogs and $45 \mathrm{E}$. coli isolates from dogs with diarrhea were investigated to phenotypic and genotypic antimicrobial resistance profiles.

In our study, the highest frequency of resistance in the healthy dogs was recorded for tetracycline $(n=13)$, ampicillin $(n=12)$, ciprofloxacin $(n=6)$, ampicillin + sulbactam $(n=6)$ and trimethoprim + sulphonamide $(n=5)$. This resistance phenotype is the most common, and this could indicate the mobile nature of the genes responsible for these resistance phenotypes [31]. Two of the isolates showed phenotypic colistin resistance.

The group of dogs with diarrhea showed a lower resistance profile for ampicillin $(n=0)$, ampicillin + sulbactam $(n=2)$ and trimethoprim + sulphonamide $(n=4)$. Only their resistance to ciprofloxacin $(n=12)$ and tetracycline $(n=14)$ was higher.

These findings are important for clinicians because $\beta$-lactam antibiotics are the most frequently used antimicrobials for gastrointestinal disease in dogs and cats [32]. Ampicillinresistant $E$. coli could still be isolated from the dogs treated with antibiotics 21 days after treatment [33]. This emphasizes the fact that the intestinal tract acts as a reservoir for resistant bacteria long after the treatment has been stopped. Different studies suggest that high levels of resistance genes can still be found up to four years after antibiotic exposure [34,35]. This once more supports the importance of prudent antimicrobial usage in order to prevent the spread of antibiotic resistance.

\subsection{Interpretative Reading of the Antibiogram and Detection of Resistance Genes}

The most commonly used antimicrobials for companion animals in Europe (e.g., Poland [36], Italy [37], Finland [38], Sweden [39], Norway [40] and the UK [41]) are $\beta$ lactams (such as ampicillin, amoxicillin and amoxicillin-clavulanate). Fluoroquinolones, macrolides, tetracyclines, nitroimidazoles and trimethoprim/sulphonamides have been also reported to be routinely used in small animal practice, but on a much smaller scale than $\beta$-lactams.

Resistance to ampicillin (AMP) was found in 12 of the E. coli isolated from healthy animals. The value of MIC 90 (minimum inhibitory concentration required to inhibit the growth of $90 \%$ of microorganisms) for AMP in this group was $64 \mathrm{mg} / \mathrm{L}$. Compared to the EUCAST clinical breakpoint (CBP) (AMP = $8 \mathrm{mg} / \mathrm{L})$, the level of our MIC was very high. Next, a very important antibiotic for this group is ampicillin + sulbactam (SAM), because it has a good safety profile and provides coverage for a wide spectrum of bacterial pathogens. Six isolates from the healthy dogs were resistant to SAM, with a MIC $90(16 \mathrm{mg} / \mathrm{L})$ value slightly lower than for AMP (CBP for SAM $=8 \mathrm{mg} / \mathrm{L}$ ), while only two such isolates were found in the dogs with diarrhea (MIC $90=8 \mathrm{mg} / \mathrm{L}$ ). These results are comparable with other studies conducted in Europe [42,43], although a higher resistance is more often reported in southern European countries [10], which supports the importance of detecting the antibiotic profile for success treatment in companion animals. From the $\beta$ - lactamase genes, we detected only simple $b l a_{\mathrm{TEM}-1}$ in six isolates from the healthy dogs.

Some of the MIC levels found in this study were worrisome. The target MIC value for colistin (COL) is $4 \mathrm{mg} / \mathrm{L}$, or exceptionally $2 \mathrm{mg} / \mathrm{L}$. An interesting finding was the detection of phenotypic colistin-resistance in our two strains from healthy dogs, specifically with values of $4 \mathrm{mg} / \mathrm{L}$ and $8 \mathrm{mg} / \mathrm{L}$ and one isolate from the dogs with diarrhea $(8 \mathrm{mg} / \mathrm{L})$. For a further study of the mechanism of this type of resistance, it is recommended that a molecular method should be used for the detection of the $m c r-1$ and $m c r-2$ genes; however, in our case, this has not been confirmed. To the best of our knowledge, COL resistance in companion animals has only been described in China [44], Germany [45], Finland [46], Ecuador [47] and the Netherlands [43]. COL is currently the last choice in the treatment of human infections caused by carbapenem-resistant enterobacteria.

The presence of tetracycline (TET) resistance was detected in the E. coli of both healthy $(n=13)$ and sick dogs $(n=14)$ with MIC $90(32 \mathrm{mg} / \mathrm{L})$. Similarly, relatively high levels 
of TET resistance have been documented in other studies of dogs; for example, in Italy, Belgium and the Netherlands [43] as well as in Poland [36]. In the past, tetracycline has been used not only to treat urinary tract infections (UTIs), but various derivates of TET (such as chlortetracycline) have been used as a growth promotor [48], and the resistance probably reflects the long history of this application. These results indicate that the resistance to TET is still growing, and it should be used only if the susceptibility of the bacteria is confirmed by an in vitro study. Resistance to TET is conferred by one or more of the described tet genes, which encode one of three resistance and efflux mechanisms that appear to be more abundant among Gram-negative microorganisms [49]. All of our isolates were examined for the presence of tet $\mathrm{A}$ and / or tet $\mathrm{B}$ genes. The most common determinant in the healthy isolates was the tetA gene $(n=19)$, while tet $\mathrm{B}$ was detected in five isolates. These results are comparable with others described by Costa et al., Torkan et al. and Yousefi et al. [50-52]. On the other hand, the isolates from dogs with diarrhea showed a higher prevalence of the tet $\mathrm{B}$ gene $(n=13)$ versus tet $\mathrm{A}(n=5)$.

Fluoroquinolone resistance is multifactorial, with both chromosomal and plasmidmediated quinolone resistance (PMQR) mechanisms that are often contributing to the overall MIC [53]. The emergence of PMQR indicates that quinolone resistance can also be acquired through a horizontal gene transfer [54], and PMQR genes can create an environment in E. coli for the rapid selection of high levels of resistance [55]. The MIC 90 of ciprofloxacin (CIP) was MIC $90=8 \mathrm{mg} / \mathrm{L}$ in both groups (Figure 1 ) and was higher than CBP $(0.5 \mathrm{mg} / \mathrm{L})$. Among the 38 healthy E. coli isolates, 16 carried PMQR genes including the $q n r \mathrm{~B}$ gene in 13 isolates, $q n r \mathrm{~S}$ in two isolates and one isolate with $a a c\left(6^{\prime}\right)-\mathrm{Ib}-\mathrm{cr}$. The isolates from dogs with diarrhea were positive for $q n r S(n=9)$ and $a a c\left(6^{\prime}\right)-\operatorname{Ib}-c r(n=2)$. As in other studies [56,57], genes encoding PMQR were also present in the ciprofloxacin-sensitive isolates, and this was not only related to the selective pressure of the fluoroquinolones used.

(a)

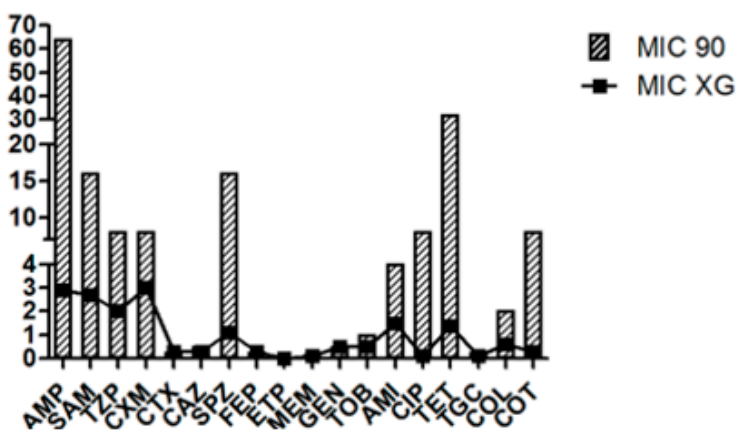

(b)

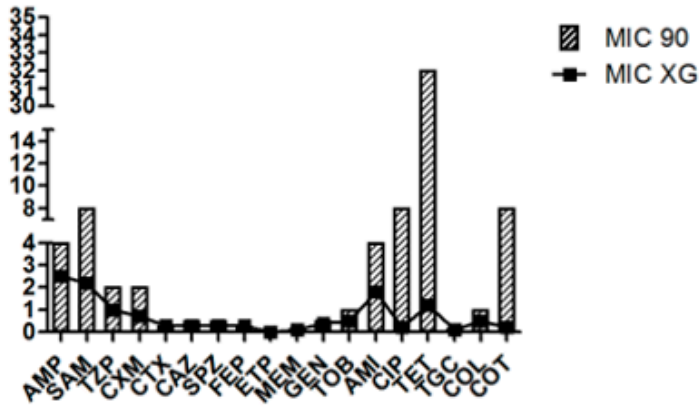

Figure 1. The values of MIC 90 and MIC XG (geometric mean MIC values of an antibiotic agent; mg/L) in E. coli of (a) healthy dogs and (b) dogs with diarrhea. Abbreviations: AMP = ampicillin; SAM = ampicillin + sulbactam; $\mathrm{TZP}=$ piperacillin + tazobactam; $\mathrm{CXM}=$ cefuroxime; $\mathrm{CTX}=$ cefotaxime; $\mathrm{CAZ}=$ ceftazidime; $\mathrm{SPZ}=$ cefoperazone + sulbactam; FEP = cefepime; ETP = ertapenem; $\mathrm{MEM}=$ meropenem; GEN = gentamicin; $\mathrm{TOB}=$ tobramycin; $\mathrm{AMI}=$ amikacin; $\mathrm{CIP}=$ ciprofloxacin; TET $=$ tetracycline; $\mathrm{TGC}=$ tigecycline $\mathrm{COL}=$ colistin and $\mathrm{COT}=$ trimethoprim + sulfonamide .

Resistance to trimethoprim-sulphonamide (COT) was detected in 11 E. coli strains from the healthy dogs and 5 isolates from the diarrheal dogs. In this study, the trimethoprim determinant $d f r A$ was harbored by three isolates of the healthy dogs. This rate of COT resistance gene acquisition is high, and may be due to selection resulting from the frequent use of the sulfonamide/trimethoprim combination (due to its broad-spectrum activity) in small animal medicine [51]. This may also explain the presence of $\operatorname{sul1}(n=1$ in the healthy dogs) and $\operatorname{sul} 2$ ( $n=9$ in the healthy dogs and $n=5$ in the dogs with diarrhea) genes in our examined isolates. These results indicate a transmission of resistance genes to the normal microflora of healthy dogs.

Antimicrobial multidrug resistance (MDR) (resistance to at the least three different classes of antibiotics) was reported in 11 isolates of the healthy dogs and 2 isolates of the 
diarrheal dogs. The presence of integron $1(i n t 1 ; n=12)$ and transposome $(t n 3 ; n=12)$ in the healthy dogs indicates that the genetic mechanism for obtaining AMR genes is present not only in clinically-obtained isolates, but also in the isolates of a normal pet's microbiota. The int 1 gene often occurs in combination with trimethoprim resistance $(d f r)$ and resistance to sulphonamide (sul), and it was detected in two isolates from the healthy dogs.

Data on pet animals is clearly needed for guiding the antimicrobial use policies in small animal veterinary practice, as well as for assessing the risk of the transmission of antimicrobial resistance to humans. Although our work evaluated antibiotic resistance without comparing our isolates to human ones, there are other existing studies that provide support for the occasional cross-host-species sharing of resistant strains, which highlights the importance of understanding the role of companion animals in the overall transmission patterns of multi-drug resistant $E$. coli with the potential for causing intestinal and/or extraintestinal infection [58,59].

\subsection{Phylogenetic Analysis and Biofilm Formation}

Focusing on the phylogenetic analysis (Figure 2), most of the strains from the healthy dog group were classified into commensal intestinal groups. In detail, 18 isolates were members of phylogroup A, and 13 were members of phylogroup B1. Pathogenic phylogroups occurred less frequently, but phylogroup B2 included three isolates; phylogroup E consisted of two isolates; one isolate fell into each of the phylogroup D and F groups.

(a)

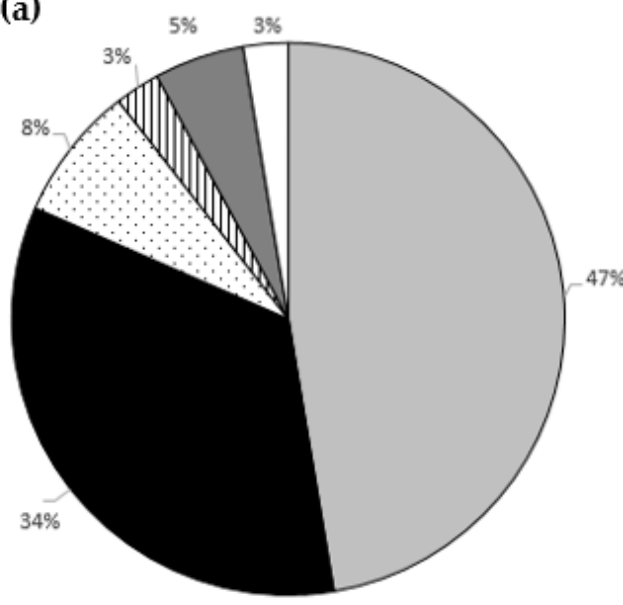

(b)

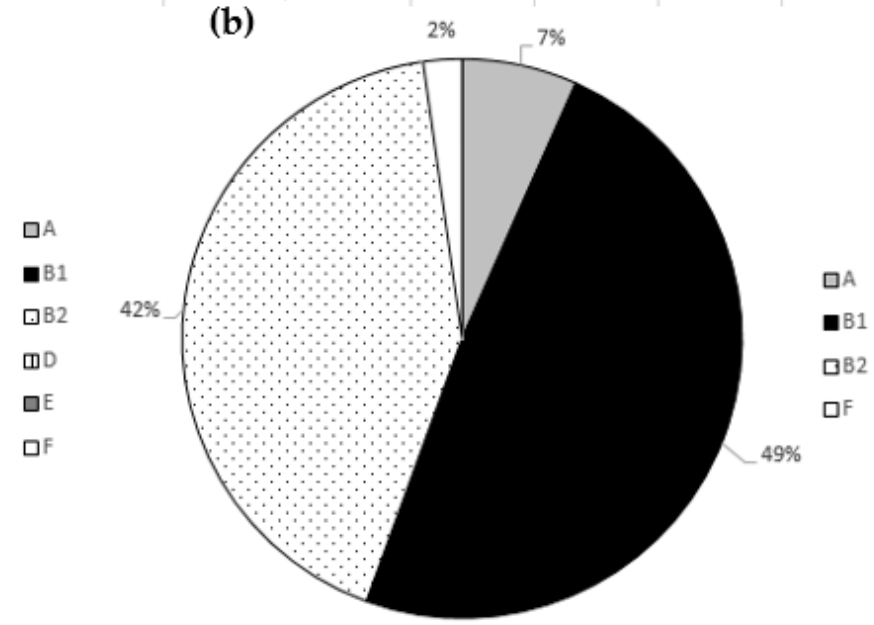

Figure 2. The E. coli phylogroup analysis in (a) healthy dogs and (b) dogs with diarrhea.

The many strains from the dogs with diarrhea were classified into B2 $(19 / 45 ; 42.2 \%)$ and B1 $(22 / 45 ; 48.90 \%)$ groups. Our comparative analysis between the phylogroups of the healthy and diarrheic dogs showed that the phylogroup B2 was visibly more common in the dogs with diarrhea.

In the healthy animals, the B1 group predominated, followed by the A, B2 and D groups [60]. These findings are important and show that the healthy dogs are colonized by commensal and pathogenic strains. The observation that the phylogenetic group B2 was usually related with the uropathogenic E. coli (UPEC) infection and the phylogenetic group $\mathrm{D}$ with the other extraintestinal pathogenic E. coli (ExPEC) has been previously reported [61,62]. Our results are comparable with those of Vega-Manriquez et al. [63], where the phylogroup analysis showed that a greater half $(57 \%)$ of the E. coli isolates from the healthy dogs belonged to the commensal A and B1 groups, in contrast to the sick dogs, where the phylogroups D and B2 were dominant. In a study by Valat et al. [64], most of the pathogenic E. coli in dogs from digestive pathologies were also assigned to the B2 phylogroup (58.6\%). 
The ability of E. coli to form a biofilm is an important virulent property. Our strains were divided into four main groups on the basis of their biofilm-producing capacity (Figure 3).

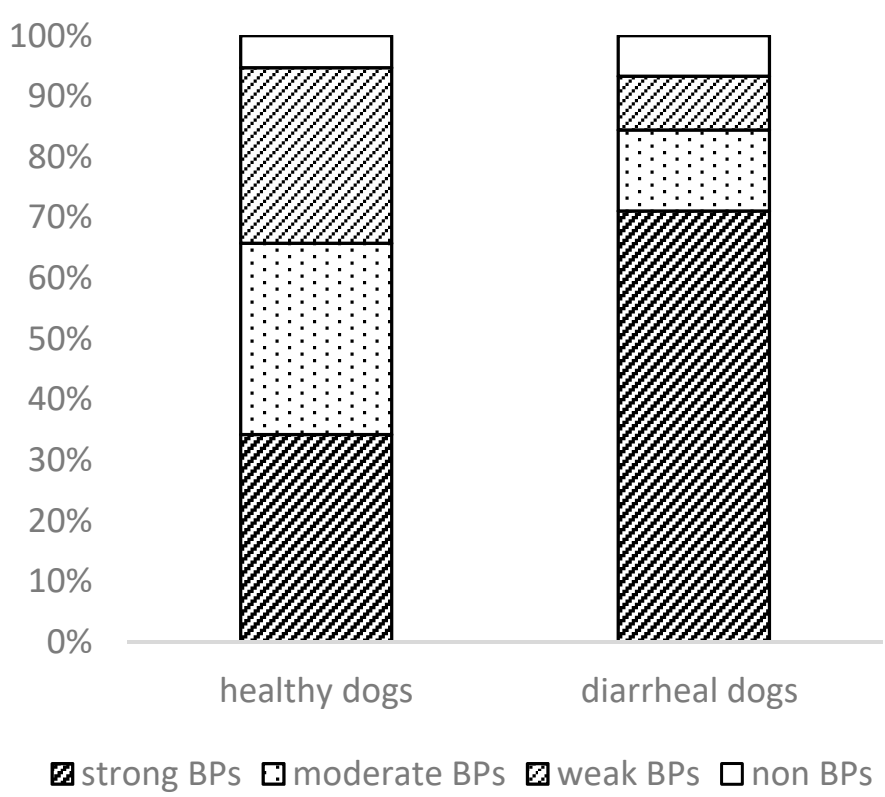

Figure 3. The ability of E. coli isolates to form biofilm.

In the healthy dogs, 13 strains (34.2\%) were classified as strong biofilm producers, while the remaining 12 strains (31.6\%) were regarded as moderate and $11(29 \%)$ as weak biofilm producers. Only two of the strains did not form a biofilm. Most of the clinical isolates $(70 \%, n=32)$ had a stronger ability to form biofilms, followed by $13 \%$ moderate and $9 \%$ weak biofilm producers. In their study, Vijay et al. [65] examined the ability to form a biofilm in enteroaggregative E. coli (EAEC) from humans and animals with diarrhea. In that case, the EAEC isolates recovered from animals were low biofilm producers (65.3\%), followed by moderate $(26.5 \%)$ and high biofilm producers $(8.1 \%)$. It has been reported $[66,67]$ that biofilm formation may be an important contributory factor in persistent infection, either by allowing the bacteria to evade the local immune system and/or by preventing the transport of antibacterial factors, including antibiotics.

The analysis between the phylogenetic groups and the presence of phenotypic AMR (Table 2) shows that $17 \mathrm{E}$. coli of the healthy dogs belonging to the commensal phylogenetic groups-A, B1-were without AMR phenotypic profile along with all examined strains belong to the pathogenic groups B2, D, E and F. The remaining 14 E. coli-part of the commensal phylogroups-showed resistance to antibiotics. The most common phenotypic AMR profile in the healthy dogs were AMP-TET-COT (phylogroup A = 2 isolates; $\mathrm{B} 1=2$ isolates) and AMP-CIP-TET-COT (phylogroup A = 2 isolates; $\mathrm{B} 1=2$ isolates). Twenty-three E. coli of the sick dogs belonging to the commensal phylogenetic groups- A, B1-were without AMR phenotypic profile, and two isolates showed phenotypic resistance only to colistin. Predominant isolates of dogs with diarrhea showed the most common form of CIP - TET combination in the B2 phylogroup $(n=7)$. Our study compared the values of MIC 90 and MIC XG (geometric mean MIC values of an antibiotic agent; mg/L) in $E$. coli of healthy dogs and dogs with diarrhea and points only to a slight increase in these values in healthy animals versus dogs with diarrhea. 
Table 2. The frequency of phenotypic antimicrobial resistance/sensitivity divided into phylogroups in healthy and sick dogs.

\begin{tabular}{|c|c|c|}
\hline Phylogroups of Healthy Dogs & $\begin{array}{l}\text { Phenotypic Antimicrobial } \\
\text { Resistance Profile }\end{array}$ & Number of Isolates \\
\hline A & Without AMR profile & $n=8$ \\
\hline $\mathrm{A}$ & TET $^{1}$ & $n=2$ \\
\hline $\mathrm{A}$ & AMP, COT & $n=1$ \\
\hline $\mathrm{A}$ & AMP, TET, COT & $n=2$ \\
\hline $\mathrm{A}$ & AMP, SAM, TET & $n=1$ \\
\hline $\mathrm{A}$ & AMP, CIP, TET, COT & $n=2$ \\
\hline A & AMP, CIP, TET, COL, COT & $n=2$ \\
\hline B1 & Without AMR profile & $n=9$ \\
\hline B1 & AMP, TET, COT & $n=2$ \\
\hline B1 & AMP, CIP, TET, COT & $n=2$ \\
\hline B2 & Without AMR profile & $n=3$ \\
\hline $\mathrm{D}$ & Without AMR profile & $n=1$ \\
\hline $\mathrm{E}$ & Without AMR profile & $n=2$ \\
\hline $\mathrm{F}$ & Without AMR profile & $n=1$ \\
\hline Phylogroups of sick dogs & $\begin{array}{l}\text { Phenotypic antimicrobial } \\
\text { resistance profile }\end{array}$ & Number of isolates \\
\hline A & Without AMR profile & $n=3$ \\
\hline B1 & Without AMR profile & $n=20$ \\
\hline B1 & COL & $n=2$ \\
\hline B2 & CIP & $n=4$ \\
\hline B2 & TET & $n=3$ \\
\hline $\mathrm{B} 2$ & CIP, TET & $n=7$ \\
\hline B2 & TET, COT & $n=2$ \\
\hline $\mathrm{B} 2$ & CIP, COT & $n=1$ \\
\hline B2 & SAM, TET, COT & $n=2$ \\
\hline $\mathrm{F}$ & Without AMR profile & $n=1$ \\
\hline
\end{tabular}

Abbreviations: AMP = ampicillin; SAM = ampicillin + sulbactam; CIP = ciprofloxacin; TET = tetracycline; $\mathrm{COL}=$ colistin and $\mathrm{COT}=$ trimethoprim + sulfonamide.

\section{Conclusions}

This study reported on a comparison of $E$. coli isolates from healthy and diarrheic dogs. The observed results in the dogs with diarrhea showed differences in the phylogenetic representation, especially in terms of a high incidence of B2 isolates that were able to form a stronger biofilm compared to isolates from healthy dogs. The MIC 90 and MIC XG monitoring pointed out only a slight increase in these values in healthy animals. However, a high prevalence of genes encoding AMR and mobile elements in commensal E. coli can indicate that these strains can be a vehicle for the spread dissemination of AMR.

Author Contributions: Conceptualization, D.B., L.K.; methodology, L.K.; validation, D.B., L.K.; writing—original draft preparation, L.K., D.B., R.M.; writing—review and editing, D.B.; supervision, D.B.; resources of isolates, R.M.; project administration, D.B.; funding acquisition, D.B. All authors have read and agreed to the published version of the manuscript.

Funding: This research was funded by VEGA grant number 2/0010/21 and Cost Action CA18217 (European Network for Optimization of Veterinary Antimicrobial Treatment).

Conflicts of Interest: The authors declare no conflict of interest. The funders had no role in the design of the study; in the collection, analyses or interpretation of data; in the writing of the manuscript or in the decision to publish the results. 


\section{References}

1. Kaper, J.B.; Nataro, J.P.; Mobley, H.L.T. Pathogenic Escherichia coli. Nat. Rev. Microbiol. 2004, 2, 123-140. [CrossRef]

2. Puño-Sarmiento, J.; Medeiros, L.; Chiconi, C.; Martins, F.; Pelayo, J.; Rocha, S.; Blanco, J.; Blanco, M.; Zanutto, M.; Kobayashi, R.; et al. Detection of Diarrheagenic Escherichia coli Strains Isolated from Dogs and Cats in Brazil. Vet. Microbiol. 2013, 166, 676-680. [CrossRef] [PubMed]

3. Majowicz, S.E.; Scallan, E.; Jones-Bitton, A.; Sargeant, J.M.; Stapleton, J.; Angulo, F.J.; Yeung, D.H.; Kirk, M.D. Global Incidence of Human Shiga Toxin-Producing Escherichia coli Infections and Deaths: A Systematic Review and Knowledge Synthesis. Foodborne Pathog. Dis. 2014, 11, 447-455. [CrossRef] [PubMed]

4. Sharma, D.; Misba, L.; Khan, A.U. Antibiotics versus Biofilm: An Emerging Battleground in Microbial Communities. Antimicrob. Resist. Infect. Control 2019, 8, 76. [CrossRef] [PubMed]

5. Ferreira, J.P.; Staerk, K. Antimicrobial Resistance and Antimicrobial Use Animal Monitoring Policies in Europe: Where Are We? J. Public Health Policy 2017, 38, 185-202. [CrossRef]

6. Collignon, P.; McEwen, S. One Health-Its Importance in Helping to Better Control Antimicrobial Resistance. Trop. Med. Infect. Dis. 2019, 4, 22. [CrossRef] [PubMed]

7. Guardabassi, L.; Schwarz, S.; Lloyd, D.H. Pet Animals as Reservoirs of Antimicrobial-Resistant BacteriaReview. J. Antimicrob. Chemother. 2004, 54, 321-332. [CrossRef] [PubMed]

8. Penakalapati, G.; Swarthout, J.; Delahoy, M.J.; McAliley, L.; Wodnik, B.; Levy, K.; Freeman, M.C. Exposure to Animal Feces and Human Health: A Systematic Review and Proposed Research Priorities. Environ. Sci. Technol. 2017, 51, 11537-11552. [CrossRef]

9. Swedres-Svarm 2019. Sales of Antibiotics and Occurrence of Resistance in Sweden. Solna/Uppsala ISSN1650-6332. Available online: www.sva.se/swedres-svarm/ (accessed on 19 March 2021).

10. The European Union Summary Report on Antimicrobial Resistance in Zoonotic and Indicator Bacteria from Humans, Animals and Food in 2014. EFSA J. 2016, 14. [CrossRef]

11. Bessède, E.; Angla-Gre, M.; Delagarde, Y.; Hieng, S.S.; Ménard, A.; Mégraud, F. Matrix-Assisted Laser-Desorption/Ionization Biotyper: Experience in the Routine of a University Hospital. Clin. Microbiol. Infect. 2011, 17, 533-538. [CrossRef] [PubMed]

12. Clermont, O.; Christenson, J.K.; Denamur, E.; Gordon, D.M. The Clermont Escherichia coli Phylo-Typing Method Revisited: Improvement of Specificity and Detection of New Phylo-Groups. Environ. Microbiol. Rep. 2013, 5, 58-65. [CrossRef]

13. Mazel, D.; Dychinco, B.; Webb, V.A.; Davies, J. Antibiotic Resistance in the ECOR Collection: Integrons and Identification of a Novel Aad Gene. Antimicrob. Agents Chemother. 2000, 44, 1568-1574. [CrossRef]

14. Weill, F.-X.; Demartin, M.; Fabre, L.; Grimont, P.A.D. Extended-Spectrum- $\beta$-Lactamase (TEM-52)-Producing Strains of Salmonella enterica of Various Serotypes Isolated in France. J. Clin. Microbiol. 2004, 42, 3359-3362. [CrossRef] [PubMed]

15. Navia, M.M.; Ruiz, J.; Sanchez-Cespedes, J.; Vila, J. Detection of Dihydrofolate Reductase Genes by PCR and RFLP. Diagn. Microbiol. Infect. Dis. 2003, 46, 295-298. [CrossRef]

16. Guillaume, G.; Verbrugge, D.; Chasseur-Libotte, M.-L.; Moens, W.; Collard, J.-M. PCR Typing of Tetracycline Resistance Determinants (Tet A-E) in Salmonella enterica Serotype Hadar and in the Microbial Community of Activated Sludges from Hospital and Urban Wastewater Treatment Facilities in Belgium. FEMS Microbiol. Ecol. 2000, 32, 77-85. [CrossRef] [PubMed]

17. Chen, X.; Zhang, W.; Pan, W.; Yin, J.; Pan, Z.; Gao, S.; Jiao, X. Prevalence of Qnr, Aac(6')-Ib-Cr, QepA, and OqxAB in Escherichia coli Isolates from Humans, Animals, and the Environment. Antimicrob. Agents Chemother. 2012, 56, 3423-3427. [CrossRef]

18. Yamane, K.; Wachino, J.; Suzuki, S.; Arakawa, Y. Plasmid-Mediated QepA Gene among Escherichia coli Clinical Isolates from Japan. Antimicrob. Agents Chemother. 2008, 52, 1564-1566. [CrossRef]

19. Robicsek, A.; Strahilevitz, J.; Sahm, D.F.; Jacoby, G.A.; Hooper, D.C. Qnr Prevalence in Ceftazidime-Resistant Enterobacteriaceae Isolates from the United States. Antimicrob. Agents Chemother. 2006, 50, 2872-2874. [CrossRef]

20. Liu, Y.-Y.; Wang, Y.; Walsh, T.R.; Yi, L.-X.; Zhang, R.; Spencer, J.; Doi, Y.; Tian, G.; Dong, B.; Huang, X.; et al. Emergence of Plasmid-Mediated Colistin Resistance Mechanism MCR-1 in Animals and Human Beings in China: A Microbiological and Molecular Biological Study. Lancet Infect. Dis. 2016, 16, 161-168. [CrossRef]

21. Xavier, B.B.; Lammens, C.; Ruhal, R.; Kumar-Singh, S.; Butaye, P.; Goossens, H.; Malhotra-Kumar, S. Identification of a Novel Plasmid-Mediated Colistin-Resistance Gene, Mcr-2, in Escherichia coli, Belgium, June 2016. Eurosurveillance 2016, 21, 30280. [CrossRef]

22. Kerrn, M.B.; Klemmensen, T.; Frimodt-Møller, N.; Espersen, F. Susceptibility of Danish Escherichia coli Strains Isolated from Urinary Tract Infections and Bacteraemia, and Distribution of Sul Genes Conferring Sulphonamide Resistance. J. Antimicrob. Chemother. 2002, 50, 513-516. [CrossRef]

23. Guerra, B.; Junker, E.; Helmuth, R. Incidence of the Recently Described Sulfonamide Resistance Gene Sul3 among German Salmonella enterica Strains Isolated from Livestock and Food. Antimicrob. Agents Chemother. 2004, 48, 2712-2715. [CrossRef]

24. Lescat, M.; Clermont, O.; Woerther, P.L.; Glodt, J.; Dion, S.; Skurnik, D.; Djossou, F.; Dupont, C.; Perroz, G.; Picard, B.; et al. Commensal Escherichia coli Strains in Guiana Reveal a High Genetic Diversity with Host-Dependant Population Structure. Environ. Microbiol. Rep. 2013, 5, 49-57. [CrossRef] [PubMed]

25. Yates, C.; Brown, D.; Edwards, G.; Amyes, S. Detection of TEM-52 in Salmonella enterica Serovar Enteritidis Isolated in Scotland. J. Antimicrob. Chemother. 2004, 53, 407-408. [CrossRef] [PubMed]

26. Rodriguez-Villalobos, H.; Malaviolle, V.; Frankard, J.; de Mendonça, R.; Nonhoff, C.; Struelens, M.J. In Vitro Activity of Temocillin against Extended Spectrum Beta-Lactamase-Producing Escherichia coli. J. Antimicrob. Chemother. 2006, 57, 771-774. [CrossRef] 
27. Pérez-Pérez, P.J.; Hanson, N.D. Detection of Plasmid-Mediated AmpC beta-Lactamase Genes in Clinical Isolates by Using Multiplex PCR. J. Clin. Microbiol. 2002, 40, 2153-2162. [CrossRef] [PubMed]

28. Gattringer, R.; Niks, M.; Ostertág, R.; Schwarz, K.; Medvedovic, H.; Graninger, W.; Georgopoulos, A. Evaluation of MIDITECH Automated Colorimetric MIC Reading for Antimicrobial Susceptibility Testing. J. Antimicrob. Chemother. 2002, 49, 651-659. [CrossRef]

29. The European Committee on Antimicrobial Susceptibility Testing. Breakpoint Tables for Interpretation of MICs and Zone Diameters, Version 10.0. 2020. Available online: https://www.eucast.org/fileadmin/src/media/PDFs/EUCAST_files/Resistance_ mechanisms/EUCAST_detection_of_resistance_mechanisms_170711.pdf (accessed on 10 October 2020).

30. Stepanović, S.; Vuković, D.; Hola, V.; Bonaventura, G.D.; Djukić, S.; Ćirković, I.; Ruzicka, F. Quantification of Biofilm in Microtiter Plates: Overview of Testing Conditions and Practical Recommendations for Assessment of Biofilm Production by Staphylococci. APMIS 2007, 115, 891-899. [CrossRef]

31. Wedley, A.L.; Maddox, T.W.; Westgarth, C.; Coyne, K.P.; Pinchbeck, G.L.; Williams, N.J.; Dawson, S. Prevalence of AntimicrobialResistant Escherichia coli in Dogs in a Cross-Sectional, Community-Based Study. Vet. Rec. 2011, 168, 354. [CrossRef]

32. German, A.J.; Halladay, L.J.; Noble, P.-J.M. First-Choice Therapy for Dogs Presenting with Diarrhea in Clinical Practice. Vet. Rec. 2010, 167, 810-814. [CrossRef]

33. Werner, M.; Suchodolski, J.S.; Straubinger, R.K.; Wolf, G.; Steiner, J.M.; Lidbury, J.A.; Neuerer, F.; Hartmann, K.; Unterer, S. Effect of Amoxicillin-Clavulanic Acid on Clinical Scores, Intestinal Microbiome, and Amoxicillin-Resistant Escherichia coli in Dogs with Uncomplicated Acute Diarrhea. J. Vet. Intern. Med. 2020, 34, 1166-1176. [CrossRef] [PubMed]

34. Jakobsson, H.E.; Jernberg, C.; Andersson, A.F.; Sjölund-Karlsson, M.; Jansson, J.K.; Engstrand, L. Short-Term Antibiotic Treatment Has Differing Long-Term Impacts on the Human Throat and Gut Microbiome. PLoS ONE 2010, 5, e9836. [CrossRef] [PubMed]

35. Jernberg, C.; Löfmark, S.; Edlund, C.; Jansson, J.K. Long-Term Impacts of Antibiotic Exposure on the Human Intestinal Microbiota. Microbiology 2010, 156, 3216-3223. [CrossRef]

36. Rzewuska, M.; Czopowicz, M.; Kizerwetter-Świda, M.; Chrobak, D.; Błaszczak, B.; Binek, M. Multidrug Resistance in Escherichia coli Strains Isolated from Infections in Dogs and Cats in Poland (2007-2013). Available online: https://www.hindawi.com/ journals/tswj/2015/408205/ (accessed on 9 October 2020). [CrossRef]

37. Escher, M.; Vanni, M.; Intorre, L.; Caprioli, A.; Tognetti, R.; Scavia, G. Use of Antimicrobials in Companion Animal Practice: A Retrospective Study in a Veterinary Teaching Hospital in Italy. J. Antimicrob. Chemother. 2011, 66, 920-927. [CrossRef]

38. Thomson, K.H.; Rantala, M.H.J.; Viita-Aho, T.K.; Vainio, O.M.; Kaartinen, L.A. Condition-Based Use of Antimicrobials in Cats in Finland: Results from Two Surveys. J. Feline Med. Surg. 2009, 11, 462-466. [CrossRef] [PubMed]

39. Odensvik, K.; Grave, K.; Greko, C. Antibacterial Drugs Prescribed for Dogs and Cats in Sweden and Norway 1990-1998. Acta Vet. Scand. 2001, 42, 189. [CrossRef] [PubMed]

40. Kvaale, M.K.; Grave, K.; Kristoffersen, A.B.; Norström, M. The Prescription Rate of Antibacterial Agents in Dogs in NorwayGeographical Patterns and Trends during the Period 2004-2008. J. Vet. Pharmacol. Ther. 2013, 36, 285-291. [CrossRef]

41. Mateus, A.; Brodbelt, D.C.; Barber, N.; Stärk, K.D.C. Antimicrobial Usage in Dogs and Cats in First Opinion Veterinary Practices in the UK. J. Small Anim. Pract. 2011, 52, 515-521. [CrossRef]

42. Marques, C.; Gama, L.T.; Belas, A.; Bergström, K.; Beurlet, S.; Briend-Marchal, A.; Broens, E.M.; Costa, M.; Criel, D.; Damborg, P.; et al. European Multicenter Study on Antimicrobial Resistance in Bacteria Isolated from Companion Animal Urinary Tract Infections. BMC Vet. Res. 2016, 12, 213. [CrossRef]

43. Joosten, P.; Ceccarelli, D.; Odent, E.; Sarrazin, S.; Graveland, H.; Van Gompel, L.; Battisti, A.; Caprioli, A.; Franco, A.; Wagenaar, J.A.; et al. Antimicrobial Usage and Resistance in Companion Animals: A Cross-Sectional Study in Three European Countries. Antibiotics 2020, 9, 87. [CrossRef]

44. Zhang, X.-F.; Doi, Y.; Huang, X.; Li, H.-Y.; Zhong, L.-L.; Zeng, K.-J.; Zhang, Y.-F.; Patil, S.; Tian, G.-B. Possible Transmission of Mcr-1 -Harboring Escherichia coli between Companion Animals and Human. Emerg. Infect. Dis. 2016, 22, 1679-1681. [CrossRef]

45. Guenther, S.; Falgenhauer, L.; Semmler, T.; Imirzalioglu, C.; Chakraborty, T.; Roesler, U.; Roschanski, N. Environmental Emission of Multiresistant Escherichia coli Carrying the Colistin Resistance Gene Mcr-1 from German Swine Farms. J. Antimicrob. Chemother. 2017, dkw585. [CrossRef]

46. Comms, V. Colistin Resistance Detected in Shelter Dogs Imported from Russia. Available online: https://www.helsinki.fi/en/ news/health/colistin-resistance-detected-in-shelter-dogs-imported-from-russia (accessed on 14 October 2020).

47. Ortega-Paredes, D.; Haro, M.; Leoro-Garzón, P.; Barba, P.; Loaiza, K.; Mora, F.; Fors, M.; Vinueza-Burgos, C.; Fernández-Moreira, E. Multidrug-Resistant Escherichia coli Isolated from Canine Faeces in a Public Park in Quito, Ecuador. J. Glob. Antimicrob. Resist. 2019, 18, 263-268. [CrossRef]

48. Grossman, T.H. Tetracycline Antibiotics and Resistance. Cold Spring Harb. Perspect. Med. 2016, 6, a025387. [CrossRef] [PubMed]

49. Chopra, I.; Roberts, M. Tetracycline Antibiotics: Mode of Action, Applications, Molecular Biology, and Epidemiology of Bacterial Resistance. Microbiol. Mol. Biol. Rev. 2001, 65, 232-260. [CrossRef]

50. Costa, D.; Poeta, P.; Sáenz, Y.; Coelho, A.C.; Matos, M.; Vinué, L.; Rodrigues, J.; Torres, C. Prevalence of Antimicrobial Resistance and Resistance Genes in Faecal Escherichia coli Isolates Recovered from Healthy Pets. Vet. Microbiol. 2008, 127, 97-105. [CrossRef] [PubMed]

51. Torkan, S.; Bahadoranian, M.; Khamesipour, F.; Anyanwu, M. Detection of Virulence and Antimicrobial Resistance Genes in Escherichia coli Isolates from Diarrhoiec Dogs in Iran. Arch. Med. Vet. 2016, 48, 181-190. [CrossRef] 
52. Yousefi, A.; Torkan, S. Uropathogenic Escherichia coli in the Urine Samples of Iranian Dogs: Antimicrobial Resistance Pattern and Distribution of Antibiotic Resistance Genes. BioMed Res. Int. 2017, 2017, 1-10. [CrossRef]

53. Martinez-Martinez, L. Interaction of Plasmid and Host Quinolone Resistance. J. Antimicrob. Chemother. 2003, 51, 1037-1039. [CrossRef]

54. Yu, T.; Jiang, X.; Fu, K.; Liu, B.; Xu, D.; Ji, S.; Zhou, L. Detection of Extended-Spectrum $\beta$-Lactamase and Plasmid-Mediated Quinolone Resistance Determinants in Escherichia coli Isolates from Retail Meat in China: ESBL and PMQR Genes in Escherichia coli. J. Food Sci. 2015, 80, M1039-M1043. [CrossRef]

55. Ishida, Y.; Ahmed, A.M.; Mahfouz, N.B.; Kimura, T.; El-Khodery, S.A.; Moawad, A.A.; Shimamoto, T. Molecular Analysis of Antimicrobial Resistance in Gram-Negative Bacteria Isolated from Fish Farms in Egypt. J. Vet. Med. Sci. 2010, 72, 727-734. [CrossRef]

56. Zhao, X.; Xu, X.; Zhu, D.; Ye, X.; Wang, M. Decreased Quinolone Susceptibility in High Percentage of Enterobacter Cloacae Clinical Isolates Caused Only by Qnr Determinants. Diagn. Microbiol. Infect. Dis. 2010, 67, 110-113. [CrossRef]

57. Aslantas, Ö.; Yilmaz, E.S. Prevalence and Molecular Characterization of Extended-Spectrum $\beta$-Lactamase (ESBL) and Plasmidic AmpC $\beta$-Lactamase (PAmpC) Producing Escherichia coli in Dogs. J. Vet. Med. Sci. 2017, 79, 1024-1030. [CrossRef] [PubMed]

58. LeCuyer, T.E.; Byrne, B.A.; Daniels, J.B.; Diaz-Campos, D.V.; Hammac, G.K.; Miller, C.B.; Besser, T.E.; Davis, M.A. Population Structure and Antimicrobial Resistance of Canine Uropathogenic Escherichia coli. J. Clin. Microbiol. 2018, 56, e00788-18. [CrossRef]

59. Carvalho, A.C.; Barbosa, A.V.; Arais, L.R.; Ribeiro, P.F.; Carneiro, V.C.; Cerqueira, A.M.F. Resistance Patterns, ESBL Genes, and Genetic Relatedness of Escherichia coli from Dogs and Owners. Braz. J. Microbiol. 2016, 47, 150-158. [CrossRef] [PubMed]

60. Tenaillon, O.; Skurnik, D.; Picard, B.; Denamur, E. The Population Genetics of Commensal Escherichia coli. Nat. Rev. Microbiol. 2010, 8, 207-217. [CrossRef]

61. Russo, T.A.; Johnson, J.R. Proposal for a New Inclusive Designation for Extraintestinal Pathogenic Isolates of Escherichia coli: ExPEC. J. Infect. Dis. 2000, 181, 1753-1754. [CrossRef] [PubMed]

62. Hutton, T.A.; Innes, G.K.; Harel, J.; Garneau, P.; Cucchiara, A.; Schifferli, D.M.; Rankin, S.C. Phylogroup and Virulence Gene Association with Clinical Characteristics of Escherichia coli Urinary Tract Infections from Dogs and Cats. J. Vet. Diagn. Investig. 2018, 30, 64-70. [CrossRef]

63. Vega-Manriquez, X.D.; Ubiarco-López, A.; Verdugo-Rodríguez, A.; Hernández-Chiñas, U.; Navarro-Ocaña, A.; Ahumada-Cota, R.E.; Ramírez-Badillo, D.; Hernández-Díaz de León, N.; Eslava, C.A. Pet Dogs Potential Transmitters of Pathogenic Escherichia coli with Resistance to Antimicrobials. Arch. Microbiol. 2020, 202, 1173-1179. [CrossRef]

64. Valat, C.; Drapeau, A.; Beurlet, S.; Bachy, V.; Boulouis, H.-J.; Pin, R.; Cazeau, G.; Madec, J.-Y.; Haenni, M. Pathogenic Escherichia coli in Dogs Reveals the Predominance of ST372 and the Human-Associated ST73 Extra-Intestinal Lineages. Front. Microbiol. 2020, 11. [CrossRef]

65. Vijay, D.; Dhaka, P.; Vergis, J.; Negi, M.; Mohan, V.; Kumar, M.; Doijad, S.; Poharkar, K.; Kumar, A.; Malik, S.S.; et al. Characterization and Biofilm Forming Ability of Diarrhoeagenic Enteroaggregative Escherichia coli Isolates Recovered from Human Infants and Young Animals. Comp. Immunol. Microbiol. Infect. Dis. 2015, 38, 21-31. [CrossRef] [PubMed]

66. Tokuda, K.; Nishi, J.; Imuta, N.; Fujiyama, R.; Kamenosono, A.; Manago, K.; Kawano, Y. Characterization of Typical and Atypical Enteroaggregative Escherichia coli in Kagoshima, Japan: Biofilm Formation and Acid Resistance. Microbiol. Immunol. 2010, 54, 320-329. [CrossRef] [PubMed]

67. Navarro-Garcia, F.; Gutierrez-Jimenez, J.; Garcia-Tovar, C.; Castro, L.A.; Salazar-Gonzalez, H.; Cordova, V. Pic, an Autotransporter Protein Secreted by Different Pathogens in the Enterobacteriaceae Family, Is a Potent Mucus Secretagogue. Infect. Immun. 2010, 78, 4101-4109. [CrossRef] [PubMed] 